\title{
COUNTERING \\ "CHINESE IMPERIALISM": SINOPHOBIA AND BORDER PROTECTION IN THE DUTCH EAST INDIES \\ Oiyan Liu
}

In 1920, Oudendijk, a Dutch envoy based in Beijing, penned the following words to address what he perceived as an Asian threat at the time:

Compared to Japanese imperialism, Chinese imperialism is different. Japan is in the process of establishing a hegemonic position in East Asia, which fosters a dangerous form of imperialist thinking in the region ... The "Chinese threat," on the other hand, is the great number of Chinese people and large-scale immigration to the Indies [that] becomes increasingly significant to the Chinese government ... Although China has not ripened its pure imperialist visions in a modern sense, it would mature in the years to follow ... Chinese imperialism could be fateful for the Dutch future. ${ }^{1}$

When writers spoke of the Asian threat between the 1920s and 1940s, they generally identified Japan as the dominant power that endangered European rule in Southeast Asia. Oudendijk's words to the headquarters in The Hague, however, reveal

${ }^{1}$ DNA 2.05.38-2787: Letter from Oudendijk to Netherlands Foreign Affairs, April 7, 1920. 
that his fear of the "yellow peril" in this period was not limited just to the growth of Japan. In fact, his message echoed Dutch despair and anxiety regarding what Oudendijk termed "Chinese imperialism." This study explores the colonial practices and policies that the Dutch empire adopted to counter the danger of that so-called Chinese imperialism, a term that has been barely used in the existing scholarship, but appears-as this essay shows-in archival sources.

A close reading of the correspondence between colonial officers in the Dutch East Indies, Dutch officials in China, and the metropolitan government in The Hague reveals that prevailing Sinophobia, particularly Dutch fear of Chinese imperialism, was more immediate and intense than their fear of an increasingly powerful Japan. The fear of China, and Chinese expansionism, particularly, stemmed from the flows of people who, the officials believed, carried Chinese imperialist thinking with them to the Dutch East Indies. Although the colonial officials worried about Japan's expansion into Southeast Asia, particularly with regards to promoting the idea of "Asia for Asians" in the region, correspondence kept in the Dutch and British archives shows that colonial authorities in the 1920s were more concerned with immediately obstructing Chinese expansionist activities in Southeast Asia than with preventing the growth of the Japanese empire.

The views expressed by the officials representing the Western empires in Asia in the 1920s, such as those of Oudendijk, illustrate their worries about the dangerous connections between the rapid growth of Chinese migration, ${ }^{2}$ China's expansion to Southeast Asia, and the spread of Chinese expansionist thinking, which appeared to be criss-crossing the Chinese and Southeast Asian waters. Alarmed by the increasing migratory movements between China and Southeast Asia, the interaction between the Chinese state and Southeast Asian Chinese communities, and migrants' awareness of Chinese expansionist ambitions, Dutch officials based in Asia anticipated that "imperialist" Chinese could eventually end Dutch colonial rule in Southeast Asia. Sinophobia was not limited to Dutch-controlled territory. As this essay will show, British colonial documents, too, revealed that the British empire was seeking measures to halt pro-Chinese propaganda being circulated in British Malaya. In fact, British antiChinese policies in the early 1920s affected how Dutch authorities formulated their own countermeasures for obstructing Chinese expansion in Southeast Asia. Therefore, although this essay focuses on the case of the Dutch East Indies, it includes a

\footnotetext{
${ }^{2}$ The Chinese population in the Dutch Indies rose from 221,438 in 1860 to 537,316 in 1900, 809,039 in 1920 , and 1,233,214 in 1930. See Li Xuemin (李學民) and Huang Kunzhang (黄芘章), “Huaren renkou”(華人人口) in Yinni Huaqiaoshi [印尼華僑史] (Guangdong: Guangdong Gaodengjiaoyu chubanshe, 1987), p. 232.

${ }^{3}$ Although Dutch fears regarding Chinese imperialism peaked in the early 1920s, Dutch paranoia about the growing Chinese population in the archipelago was present as early as the late seventeenth century. In the last decades of the VOC (Vereenigde Oost-Indische Compagnie, Dutch East India Company) era, company officials feared that increasing Chinese migration could potentially threaten the company's authority in VOC-controlled territories. Until the end of the VOC period, company officials were concerned about Chinese penetration to the central and eastern parts of Java. In order to limit the growth of migrants and the territorial extension of their influence, the company imposed immigration restrictions for the first time in 1711. Company officials in Batavia and Semarang also avoided renting land and villages along the coast to the Chinese, as a way to assert and protect the company's political authority. Despite introducing migration restrictions and limitations on land tenancy, however, the VOC failed to decrease the growing economic power of the Chinese. See Kwee Hui Kian, The Political Economy of Java's Northeast Coast, c. 1740-1800: Elite Synergy (Leiden and Boston, MA: Brill, 2006), pp. 160-62.
} 
discussion of British anti-Chinese policies as well. A look at the British case sheds light on why the Dutch empire's representatives formulated their policies in this period in the way they did.

Prior to 1920, the term "Chinese imperialism" did not appear in colonial writings. The appearance of this term to describe "the Chinese threat" signified a change in the colonial perception of the Chinese presence. Many studies about the Indies Chinese in the late Dutch colonial era have described why Dutch colonial authorities felt threatened by the Indies Chinese, causing them to launch a series of anti-Chinese policies directed at the Indies Chinese in the nineteenth century. What is missing in the existing scholarship is a profound discussion of how the Dutch empire dealt with the Chinese threat in the 1920s. During this period, the colonial officials no longer considered the Chinese community residing in the Dutch colony as the main source of the Chinese threat. Starting from the first decade of the twentieth century, it became increasingly evident that Sinophobia was engendered by a larger force, namely, a China that could potentially endanger Dutch rule. By the end of the second decade, the Chinese threat, in the eyes of Dutch officials, had magnified its geographical scale and intensity in the region. That change in perceived threat, as viewed through imperial and colonial eyes, required a significant change in policies for safeguarding colonial rule. Whereas prior to the 1900 s, Dutch measures primarily focused on containing the power of the settled Chinese community within the Indies, the 1920s was an era during which the Dutch attempted to impede the traffic between China and the Indies by tightening border controls and transforming educational policies. Hence, I consider the early 1920 s as an important period that introduced a change in Dutch policies towards "the Chinese threat." I argue that the shift in colonial policies and attitudes regarding borders and education was a colonial reaction to the heightened fear over Chinese imperialism.

To place this perceptual change in a historical perspective, and to gain insight regarding how colonial authorities came to interpret a threat they had previously seen as local now to be regional and "imperialist," this essay first draws on secondary literature to summarize the main features of pre-1920s Dutch policies against the proliferation of the local Chinese "threat." What follows next forms the core of the essay. Relying on archival sources, I discuss what measures Dutch authorities took for countering what they regarded as "Chinese imperialism" in the 1920s. For the purpose of understanding why the Dutch formulated certain policies, this section will be preceded by a short review of British anti-Chinese policies in that period.

\section{The Border and Shifting Perceptions of the Chinese Threat}

Dutch strategies for countering the Chinese threat by establishing border controls did not start in the 1920s. In fact, a century earlier, colonial authorities used "borders" and "boundaries" to limit the mobility of the Chinese in the Indies, in terms of both their physical and social (upward) mobility. When Dutch authorities legally drew the racial lines in 1854 with governmental regulation RR 109, they further cemented the Indies' stratified population layers into what Furnivall called "The Plural Society," that is, a society in which different groups of Indies residents lived separately yet side-by- 
side under one political entity. ${ }^{4}$ In the following decades, the Dutch government used its imposed racial boundaries further to control the spatial, economic, and social mobility of the colonized people, including those categorized as "Chinese people." ${ }^{5}$

Around the mid-nineteenth century, the Dutch clearly changed their overall policy from privileging the Chinese during the early VOC (Vereenigde Oost-Indische Compagnie, Dutch East India Company) period, to discriminating against them in the era of high imperialism. At first, the Dutch relied on the Indies Chinese, who were predominantly merchants, and their domineering economic positions-developed thanks to their regional and inter-island networks-to increase the Empire's revenue. ${ }^{6}$ Chinese retail trade flourished as Europeans arrived in Asia. The Dutch granted mercantile privileges to the Chinese, enabling the Chinese to consolidate their power further and diversify their economic activities and professions in the archipelago. The Chinese came to hold an important intermediate position in what Wertheim called "a colonial caste structure. ${ }^{7}$ This racially stratified system created opportunities for the Chinese to hold positions situated between the Indonesian masses and a small number of Europeans who held positions at the upper levels. On behalf of the Dutch government, the Chinese mainly worked as tax farmers and pawnshop operators, and were engaged in the salt monopoly and opium trades. They were able to extend their personal commercial networks from these ventures into the money-lending business, wholesale trade, and product acquisition for the export market. ${ }^{8}$ They also solidified their position with the government's monopoly lease system (the so-called pachtstelsel), under which the Chinese leased monopoly rights for salt, tobacco, and opium in the VOC's designated territory. The pachtstelsel enabled the Chinese to dominate trade within the archipelago-among the islands, as well as between the hinterland and urban areas. Besides granting them economic power, this system also conferred on Chinese merchants the status of "government agent," giving them leased government authority over the native population. ${ }^{9}$

\footnotetext{
${ }^{4}$ J. S. Furnivall, Netherlands India: A Study of Plural Economy (Cambridge: The University Press, 1939), p. xv.

${ }^{5}$ RR 109 of 1854 divided the colonial population according to racial lines. This racial classification made legal discrimination an accepted principle. After the declaration of RR 109, the Dutch government introduced regulations according to different racial categories, namely Europeans, Inlanders (natives), and Foreign Orientals. See C. Fasseur, "Cornerstone and Stumbling Block: Racial Classification and the Late Colonial State in Indonesia," in The Late Colonial State in Indonesia: Political and Economic Foundations of the Netherlands Indies 1880-1942, ed. Robert Cribb (Leiden: KITLV Press, 1994), pp. 35-37.

${ }^{6}$ For the history of Chinese trading communities and their role in flourishing Sino-Southeast Asian trade from the thirteenth to eighteenth centuries, see, for instance, Anthony Reid, "Flows and Seepages in the Long-Term Chinese Interaction with Southeast Asia," in Sojourners and Settlers: Histories of Southeast Asia and the Chinese, ed. Anthony Reid (St. Leonards, NSW: Asian Studies Association of Australia in association with Allen \& Unwin, 1996), pp. 15-49.

${ }^{7}$ J. A. C. Mackie and Charles A. Coppel, "A Preliminary Survey," in The Chinese in Indonesia, ed. J. A. C. Mackie (Honolulu: The University of Hawaii Press, in association with The Australian Institute of International Affairs, 1976), p. 4.

${ }^{8}$ Ibid., pp. 4-5.

${ }^{9}$ Cator stated that the monopoly-lease system was one of the most important factors that contributed to Chinese penetration in Java. By way of lease-granting contracts, large areas of land became administered by the Chinese. The Chinese became private holders of leased land with chartered rights. This also allowed them to possess leased government authority over the indigenous population. See W. J. Cator, The Economic Position of the Chinese in the Netherlands Indies (Chicago, IL: The University of Chicago Press, 1936), pp. 18-24; and George McTurnan Kahin, "The Political Position of the Chinese in Indonesia" (unpublished MA Thesis, Stanford University, 1946), pp. 7-20.
} 
However, the privileged position of the Chinese changed dramatically in the nineteenth century. Fearing the Chinese's growing power, and in line with the colonial government's primary stated principles (to insure people's protection against oppression and maintain security or peace and order: openbare rust en orde), the Dutch sought to weaken the power of the Indies Chinese by implementing the following policies: revisions to the Cultivation System (Cultuurstelsel), and the introduction of the Liberal System and Ethical Policy. ${ }^{10}$ The Cultivation System in the early 1830s, which focused on export-oriented crop production for the global market, ultimately helped strengthen and consolidate Chinese economic control over rural markets and the economic activities of the native population. ${ }^{11}$ However, even as they introduced the Cultivation System, the Dutch also imposed rules to restrict the mobility of the Chinese by geographically confining them in residential quarters (wijkenstelsel) and further restricting their freedom of movement with a pass system (passenstelsel). The Dutch argued that such restrictions were necessary to control economic activity and Dutch profits. ${ }^{12}$ Cultuurstelsel was abolished in 1870 , as it had proven ineffective, but Dutch authorities continued enforcing strict restrictions on Chinese travel and residency. For example, the Indies Chinese who boarded ships with the intention of leaving the designated district or the Indies without a proper pass were detained and charged with attempting to escape; ${ }^{13}$ this was true for both peranakan (Sino-Malay people whose ancestors migrated from China and settled in the archipelago for many generations) or singkeh (new immigrants from China).

\footnotetext{
${ }^{10}$ Furnivall identified three stages outlining how the Dutch tried to protect its people. Around 1800, Dutch officials maintained that it was their duty to protect commoners against oppression. During the liberal period (1870-1900), Dutch authorities stated that it was their duty to protect people against native chieftains and planters. It was in this period that the Dutch colonial government started to prevent private planters from maintaining political and economic control. With the liberal system, foreigners (such as Chinese) were not allowed to possess native land, because the government feared that large sections of land would then be transferred to planters and Chinese moneylenders. Emphasis on the native population's welfare was further promoted during the Ethical Policy period, at the turn of the twentieth century. Although Dutch authorities upheld these principles, the government had problems with implementing the policies effectively. See J. S. Furnivall, Colonial Policy and Practice: A Comparative Study of Burma and Netherlands India (New York, NY: New York University Press, 1956), pp. 219-30.

${ }^{11}$ M. R. Fernando, "Introduction," in Chinese Economic Activity in Netherlands India: Selected Translation from the Dutch, ed. M. R. Fernando and David Bulbeck (Singapore: Institute of Southeast Asian Studies, 1992).

${ }^{12}$ The quarter system put foreigners of the same nationality in the same quarter. It was implemented in 1800 to monitor colonial populations and to keep them separate. Residents in these quarters needed permission to travel outside their quarter, a regulation imposed by the pass system. However, in 1846, Dutch gave foreigners permission to populate new settlements that were favorable for trade. Travel and residential restrictions were intended to contain Chinese economic activity in the interior, but it unintentionally helped Chinese merchants to penetrate new areas and consolidated their position in the rural markets. It enabled the Chinese to establish officially approved trading centers that functioned as exterritorial regions separated from the native surroundings. But the permit and quarter systems also had a negative effect on the Chinese, as they affected the economic structure of the Chinese population by preventing small farmers from spreading over the archipelago. See James Rush, Opium to Java: Revenue Farming and Chinese Enterprise in Colonial Indonesia, 1860-1910 (Ithaca, NY, and London: Cornell University Press, 1990), Chap. 5, pp. 87-89; Cator, The Economic Position of the Chinese in the Netherlands Indies, p. 35; and G. William Skinner, "Creolized Chinese Societies in Southeast Asia," in Sojourners and Settlers: Histories of Southeast Asia and the Chinese, ed. Anthony Reid (St. Leonards, NSW: Asian Studies Association of Australia in association with Allen \& Unwin, 1996), pp. 69-70.

${ }^{13}$ Wen Guangyi [溫䖒益], Cai Renlong [蔡仁龍], Liu Aihua [劉愛華], and Luo Mingqing [駱明卿], "Huaqiao minzu yishi de juexing ji gi yu Zhongguo geming yundong he dangdi minzu duliyundong de

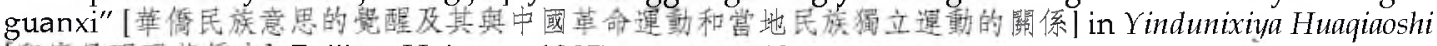
[印度尼西亞華僑史] (Beijing: Haiyang, 1985), pp. 297-300.
} 
The purpose of creating geographical boundaries within the colony and restricting Chinese mobility by way of the pass and district systems was twofold. On the one hand, Dutch authorities attempted to monitor and control Chinese economic activities as a way of safeguarding the colony's and empire's economic interests. That is, the Dutch hoped to contain Chinese expansion and dominance in trade and monopolies while simultaneously relying on Chinese networks and middlemen to increase the state's revenue. On the other hand, the regulations were meant to help prevent the commingling of races. The Dutch government deliberately segregated the Chinese from the native population. By drawing geographical units according to sharp racial distinctions, the Dutch authorities hoped to monitor the colonial population. ${ }^{14}$ In particular, the Dutch wanted to prevent the Chinese from operating like a native group for the purpose of evading taxation (the Chinese were obliged to pay higher taxes), as well as to prevent them from claiming too large a share of potential Dutch profits and spreading seditious thoughts among natives that would threaten Dutch rule. ${ }^{15}$

During the Liberal System period, the Dutch further targeted the Chinese. Liberalists regarded the Chinese as opportunists and as a threat to the colony. Therefore, concerned about the welfare of the indigenous population and desiring to protect the colony's own economy, they enforced strict controls on the Chinese. Regarding the Chinese as oppressors of the native Javanese population, Fock, for instance, stated "[t]he Chinese exercised pernicious influence in the interior." 16 This view was further strengthened during the anti-opium campaign, with the added argument that the power of opium corrupted the government's institutions. ${ }^{17}$

The image of Chinese as a menace persisted during the Ethical Policy years, a period in which the Dutch launched a series of welfare programs for natives, such as a state-sponsored educational initiative, but excluded the Chinese from making use of those benefits. ${ }^{18}$ Dutch authorities stated that the goal was to protect the indigenous population from the exploitation of Chinese people who belonged to a pernicious race and mistreated natives. ${ }^{19}$

Although the district and pass systems were initially not exclusively applied to the Chinese, but were introduced to monitor the entire colonial population to protect Dutch interests, over the course of several decades these regulations, along with other anti-Chinese policies concerning taxes, citizenship issues, and equal treatment, formed the core of Chinese grievances.

As the scholarship on Indonesian Chinese has shown, Dutch restrictions on the Chinese were implemented to curb the growing power of the Indies Chinese, whom

\footnotetext{
${ }^{14}$ In "Census, Map, Museum," Benedict Anderson described how, in the nineteenth century, the newly invented census revealed how the colonial state imagined its colonized people. He states that the racial aspect became more prominent in census categories as the colonial period progressed. See Benedict Anderson, Imagined Communities: Reflections on the Origin and Spread of Nationalism (London and New York, NY: Verso, 2000 [1983], pp. 163-70.

${ }^{15}$ Skinner, "Creolized Chinese Societies in Southeast Asia," p. 69.

${ }^{16}$ Furnivall, Netherlands India: A Study of Plural Economy, p. 239.

${ }^{17}$ James Rush, Opium to Java, Chap. 10.

${ }^{18}$ Ibid., Chap. 11.

${ }^{19}$ Patricia Tjook-Liem, De rechtspositie der Chinezen in Nederlands-Indie 1848-1942: Wetgevingsbeleid tussen Beginsel en Belang (Leiden: Leiden University Press, 2009), pp. 297-333.
} 
the Dutch saw as threat. ${ }^{20}$ However, the meaning of "the Chinese threat" changed in the first two decades of the twentieth century. Whereas in the nineteenth century the Dutch targeted the Indies Chinese as the core of the Chinese threat that would endanger the power of the colonizer and disadvantage the natives, in the twentieth century the perceived threat shifted from the Indies Chinese communities to mainland China, which increasingly intervened in Dutch Indies Chinese affairs. This change in perception started when Chinese reformers, revolutionaries, state officials, and a large number of coolies from China entered the Dutch Indies, causing the Dutch colonial government to increase surveillance measures and prevent people's movement with high taxes, strict rules regarding mobility, and harsh treatment. As a result of these developments, by the early 1920s Dutch authorities had become convinced that their own Sinophobia was generated by external forces, particularly the Chinese Nationalist government. European authorities were particularly anxious about the spread in the colonies of anti-Western attitudes and ideologies derived from China. As a result, in order to alleviate Indies Chinese grievances and regain their political support, the Dutch government gradually relieved its border restrictions and racial boundaries. After 1904, the Dutch colonial government relaxed many regulations; in 1914, it removed its restrictions for traveling within Java and Madura, and in 1918 for traveling from these places to the Outer Islands. ${ }^{21}$ Thus, instead of targeting Indies Chinese mobility within the colony, the Dutch Empire shifted its focus on imposing boundaries and borders to limit influences that were arriving from outside its territory.

What measures did Dutch authorities take to prevent unwelcome political ideas from seeping into their colony? My argument, based on archival sources, will show that more and stricter colonial-protection policies resulted from the perceived escalating Chinese "threat." Focusing on the exchange of ideas that Dutch authorities defined as "Chinese imperialism," the remainder of this essay examines various border control and educational restrictions that the Dutch empire imposed for the purpose of eradicating Chinese expansionism on its territory. In order to gain a more complete understanding of Dutch actions, it is important first to discuss the British strategy of resisting the proliferation of anti-Western political ideas in the Straits Settlements, because British policy influenced Dutch actions on the same matter.

\section{Protecting the Colonial Borders: Controlling the Flows of Thought}

The British Straits Settlements

In 1920, the British colonial government launched its Education Bill in the Straits Settlements with the purpose of controlling what they perceived as an influx of overseas Chinese propaganda in their colonies. With this ordinance, British authorities wanted to exert ideological control over their colonial subjects. The goal of this bill was to remove all political propaganda that was hostile to British authority. British officials declared schools that disseminated Guomindang's (The Chinese Nationalist Party, hereafter GMD) propaganda to be illegal institutions and forced those schools to close.

${ }^{20}$ This view of the Chinese was not limited to the Dutch colony, but also prevailed in Southeast Asia and the United States.

${ }^{21}$ W. J. Cator, The Economic Position of the Chinese in the Netherlands Indies, pp. 32-33. 
One of the clauses in the ordinance declared: "[i]f the Governor in Council considers that any school is being used for purposes of political propaganda detrimental to the colony's interests, he may after giving due notice to the manager, declare such school an unlawful one." ${ }^{22}$ In order to remove all political content at Chinese schools, this ordinance not only declared the British colonial government's right to perform periodic school inspections, but also required all existing and new schools to be registered with the Director of Education. Schools that failed to register were forced to shut down. Moreover, all staff members of these schools, including teachers and managers, were required to register, too.

The Straits Chinese objected to this policy because, unlike English and Malay vernacular schools, Chinese schools were established without government assistance and were financed with private funds from wealthy Chinese ${ }^{23}$ The ordinance ignited panic among the Chinese in the British colonies. Mass demonstrations among local Chinese erupted, propelling the Straits Chinese to petition the Chinese government. The protestors requested that Chinese authorities act on their behalf to ask the British government to nullify the regulation. The Penang Chinese Chamber of Commerce, for instance, held an urgent committee meeting. ${ }^{24} \mathrm{~V}$. K. Wellington Koo, a diplomat who participated in the Paris Peace Conference in 1919, acted on the Straits Chinese request and asked the British government to lift its colonial policy. He explained that Chinese residents in the British colony, who constituted more than 50 percent of the colonial population, were filled with fear. ${ }^{25}$

The Straits Chinese attempted to lift the restrictions in two ways. First, they requested that Chinese officials speak with British authorities on a diplomatic level, and, second, at the same time, they sent two representatives of the Straits Chinese community to London to discuss this issue directly with British imperial government leaders. ${ }^{26}$ The Straits Chinese were concerned that the Education Bill would cause a serious setback for Chinese education, because the functioning of Chinese schools relied on the supply of teachers recruited from China (many of whom were steeped in GMD doctrine and political thought) ${ }^{27} \mathrm{~A}$ few months later, in August 1921, British authorities stated that the colonial government would not interfere with Chinese schools, with Chinese-language instruction, or with the use of Chinese textbooks if those teaching facilities and materials did not contain teachings that would harm the welfare of the British empire. ${ }^{28}$

British authorities attempted to eliminate ideological indoctrination that was hostile to British authority in Malaya by exerting strict control on the circulation of proChinese and anti-British teachings. However, after the British launched the Education Bill of 1920, GMD became more aggressive in advocating anticolonialism. Not being

${ }^{22} \mathrm{CO} 273 / 510 / 49105$, Registration of Schools Ordinance 21 of 1920, clause 19 (1).

${ }^{23} \mathrm{CO} 273 / 510 / 49105$ (June 7, 1921).

${ }^{24} \mathrm{CO} 273 / 510 / 52960$ (September 1921).

${ }^{25} \mathrm{CO} 273 / 510 / 49105$ (May 2, 1921).

${ }^{26} \mathrm{CO} / 273 / 510 / 44887$; CO 273/511/3578.

${ }^{27} \mathrm{CO} 273 / 510 / 49105$ (May 2, 1921).

${ }^{28} \mathrm{CO} 273 / 511 / 3578$, December 26, 1921, “Reply to the Hon'ble Mr. P. T. Allen to a question by the Hon'ble Mr. Song Ong Siang on the working of the Registration of Schools Ordinance." 
able to spread its political message in the British colonies, GMD used schools in China as the center for ideological indoctrination for overseas Chinese students. Particularly, Jinan College, the school that the Qing empire especially opened and designed for overseas Chinese and operated under the guidance of GMD in the post-Qing era, became increasingly vocal against the British empire. ${ }^{29}$ By the mid-1920s, China's war against British imperialism climaxed when British colonial authorities, fearing that an imperium in imperio might be organized on British territory, repeatedly launched policies to eradicate GMD branches and Sun Yat-sen's influence in Malaya ${ }^{30}$ Great Britain's aggressive strategy against the GMD in British Malaya and Hong Kong escalated China's hostility towards the British empire.

It was in the years leading up to the height of Sino-British tension that Jinan became a training center where students were expected to become agents of spreading pro-Chinese and anticolonial sentiments in the European possessions. In 1922, decades before British Malaya and Singapore won independence from Britain, a Jinan lecturer expressed his opinion that a new independent country encompassing the Malay Peninsula and the Straits Settlements would be born. He stated:

... the masters of this new political division will certainly be Chinese ... I do not advise you to revolt against the British authority at once, because first you must be prepared yourself to organize a government and conduct affairs, otherwise even if the British authority should be overthrown, you will be helpless. Now is the time for you to build up your political ability, because the future masters of the Malay Peninsula are you students of this College. ${ }^{31}$

Due to Jinan's mission of nurturing its students to take over political rule of the European possessions in Southeast Asia, British colonial authorities described Jinan as the main fortress of Chinese imperialism in the modern era, and one that should not be welcomed or supported by colonial powers in Asia. ${ }^{32}$ But Jinan did not target the British as its main enemy when it reopened, after being shut down, in 1917. British intelligence analysts revealed it was not until 1920, when the British government launched its Education Bill, that the British empire became Jinan's key target in its fight against Western imperialism. Jinan's anti-British attitude was stimulated by overseas Chinese complaints. According to colonial reports, the Chinese residing in the Straits Settlements and Sumatra requested admission to Jinan only after they complained to the Chinese government that British authorities had passed laws that restricted Chinese education in the Malay Peninsula. ${ }^{33}$

British intelligence officers were convinced that Jinan at the time of its founding in 1906 and at its reopening in 1917 (or 1918), was not guided by anti-British motives ${ }^{34}$ It reported that, compared to Jinan, "Chin Bee" College, in Xiamen, demonstrated more

\footnotetext{
${ }^{29}$ Jinan, established in Nanjing in 1906, was also referred to as "the Java school" in its early years. It closed after the fall of the Qing Dynasty (1912) and reopened in Shanghai in 1917.

${ }^{30}$ Victor Purcell, The Chinese in Malaya (Kuala Lumpur: Oxford University Press, 1967), pp. 213-18.

${ }^{31} \mathrm{CO} 273 / 520 / 23272$; MBPI, no. 8 (October 1, 1922), section 41.

${ }^{32}$ DNA 2.05.90-528, Afschrift Kantoor voor Chineesche Zaken No. 514/ 23, Zeer Geheim (Weltevreden, September 13, 1923).

${ }^{33}$ MBPI no. 8 (October 1, 1922), p. 42.

${ }^{34}$ Classes started in 1918, but preparations to reopen the school started in 1917.
} 
anti-British tendencies and an overall political agenda that was more hostile to British authority than was Jinan's. The school's president, Lim Boon Keng, a Chinese from the Straits Settlements, was a fervent supporter of the British empire, but became increasingly oriented towards China after British authorities decreed that Straits Chinese of non-European descent would be ineligible to receive Queen scholarships and take on high positions in civil administration. After the fall of the Qing Empire and the founding of the Republic of China, Lim became increasingly supportive of China. He served as Chinese consul to Surabaya in 1913 and 1914, and became president of Xiamen University, which was mostly funded by Tan Kah Kee, a Chinese who was born in Xiamen, but who built a business empire in Singapore. Yet, despite China's stated ambition to expand to Southeast Asia, British leaders did not seem to be as worried about China's threat as were Dutch authorities, for, according to British authorities, the Chinese realized they lacked the political ability to do so. ${ }^{35}$ Therefore, British authorities did not mitigate their anti-Chinese policies. In fact, the colonial government further intensified its efforts to eliminate political influences that came from China. In 1927, a few years after the British colonial government launched the Education Bill with the purpose of eradicating GMD's ideological indoctrination, it declared all GMD branches as illegal associations. The British concentrated their war on Chinese expansionism in the British possessions. Despite Jinan's anti-British standpoint, the British did not directly confront Jinan. Instead, they focused on eliminating GMD's political ideas and influence.

\section{The Dutch East Indies}

British enactment of the 1920 Education Bill motivated Dutch authorities to reinforce their border policy and restrictions on Chinese education in the Indies. Already starting from at least 1907, as noted above, Dutch colonial authorities sought ways of preventing Chinese officials, educational examiners, and teachers from entering the Indies, but found that immigration rules were insufficient to cut off all influences and the interference from China that seemed to be flowing into the colony. In January 1920, the Secretary of the Government suggested enforcing strict border controls and restricting people from entering the colony altogether. ${ }^{36}$ However, it was not until 1922, after the British had launched the 1920 Education Bill, that the Dutch government launched a more aggressive policy to control the spread of what was called "Chinese imperialism." According to Dutch officials, Chinese expansionism was primarily based on educational networks linking China and Southeast Asia. Therefore, Dutch colonizers naively assumed that tightening anti-Chinese policies that were fashioned after the British empire's strict educational policies would dispel the impression that the Dutch were the greatest oppressor of Chinese people. ${ }^{37}$

Yet in Chinese and overseas Chinese writing the Chinese under Dutch rule were often depicted as a group that received even harsher treatment than did their fellows

\footnotetext{
${ }^{35}$ MBPI no. 8, p. 42.

${ }^{36}$ DNA 2.05.90-528, Bijdrage voor het Pekingrapport van 1922 no. 53 (Weltevreden, August 19, 1922):

"Overheidscontrole op particulier Chineesch Onderwijs" (Governmental Control of Chinese Private Schools).

${ }^{37}$ Ibid.
} 
residing in the British colonies. Due to close relationships between Straits Chinese and the Chinese in Java, Indies Chinese often compared their position and life situations with those of the Chinese under British rule. ${ }^{38}$ Although the British colonial government also enforced a racial stratification system, the Chinese in the Straits Settlements enjoyed more rights and freedoms than did those under Dutch control. Unlike the Dutch, who did not formally assign a legal status to Indies Chinese, the British regarded those born in the Straits Settlements as British subjects regardless of race. The British also did not impose residence and travel restrictions within the British colony, and did not discourage commingling of races. ${ }^{39}$ Therefore, the Dutch government used the British Education Bill of 1920 as a sign that British anti-Chinese policies were growing more aggressive than Dutch policies.

Although Dutch authorities did not radically sharpen their own border and educational policies until the British had enforced their education bill, the Dutch colonial government initiated its efforts to block the proliferation of Chinese schools and their ideological influences more than a decade before British authorities actively sought to eradicate the influences of Chinese education on the colonial population. Already, since the earliest stages of China's expansion into Southeast Asia, by way of migration at the beginning of the twentieth century, Dutch metropolitan and colonial governments sought ways to curb China's influence on the Indies Chinese. They countered China's interference on Indies Chinese affairs on Dutch territory by repeatedly using the so-called afweer-politiek (politics of defense), particularly in the fields of politics, education, and commerce. Yet after maintaining this campaign against Chinese imperialism for more than a decade and a half, Dutch authorities realized it had not succeeded. From the Dutch state's perspective, although the Dutch campaign was relatively successful in promoting naturalization and advancing political issues that helped attract support from the Indies Chinese, it failed to make satisfactory progress in limiting China's educational influences. ${ }^{40}$

Evaluating China's expansionist strategies in 1922, Dutch officials concluded that education was China's most effective means for expanding its sphere of influence

\footnotetext{
${ }^{38}$ There was a close relationship between Indies Chinese and Straits Chinese. The Chinese from Singapore played an important role in re-sinicizing the Indies Chinese. The Confucian revival movement in Singapore that argued for adopting a modern interpretation of Confucianism revived interest in Chinese language and culture, promoted social reforms such as education, strengthened women's positions, and eliminated outdated Chinese traditions, and that movement soon spread to the Indies. Lim Boon Keng, a leader of the Confucian revival movement in Singapore, played an important role in spreading the movement to the Indies. He gave lectures in Java, requested two Chinese from Java, Tan Ging Tiong and Yoe Tjai Siang, to translate the Confucian classics into Malay, and played an advising role in appointing educators and designing curricula for the first Chinese schools in Java. See Tan Ging Tiong and Yoe Tjai Siang, Kitab Tai Hak-Tiong Iong (Soekaboemi: Soekaboemische Snelpersdrukkerij, 1900); "Chinese Schools in Java," The Straits Chinese Magazine 10,2 (June 1906), p. 100; Yen Ching-Hwang, "The Confucian Revival Movement in Singapore and Malaya, 1899-1911," Journal of Southeast Asian Studies 7,1 (March 1976): 3357; Ming Govaars-Tjia, Dutch Colonial Education: The Chinese Experience in Indonesia, 1900-1942 (Singapore: Chinese Heritage Centre, 2005), pp. 54-55, 62-63; Song Ong Siang, One Hundred Years' History of the Chinese in Singapore (Singapore: University of Malaya Press, 1967), pp. 235-36; and "Tiong Hoa Hwe Koan," The Straits Chinese Magazine 4,16 (December 1900), p. 183.

${ }^{39}$ Skinner, "Creolized Chinese Societies in Southeast Asia," pp. 70-71.

${ }^{40}$ DNA 2.05.90-528, Bijdrage voor het Pekingrapport van 1924 no. 24: "Betreffende de al -of niet wenschelijkheid van een bezoek door onzen Consul Generaal te Shanghai and de Chinan-school te Nanking." Dutch Consul General in Shanghai visited Jinan in Nanjing on December 21, 1923.
} 
beyond its borders. Dutch authorities regarded Chinese education as a vehicle of "Chinese imperialism," and realized that it was a powerful tool for feeding a sense of Chinese nationhood. According to the Dutch government, out of several methods that China had used for building a "Young China," education had been the most effective. Education was most threatening for Dutch rule because, according a Dutch official, "this type of nationalism was anti-Western and contained imperialistic tendencies." 41 Private Chinese education, which was unsupervised by Dutch officials, was especially dangerous because, according to the Dutch government, education about the history of Chinese governance incited people of Chinese descent to work to establish a "Young China," a collective entity guided by nationalist, anti-Western, and imperialist characteristics. ${ }^{42}$ For this reason, Dutch authorities continuously tried to eliminate the influence of Chinese private schools.

The first Chinese private school, known as "Sekolah Tjina THHK" (Tiong Hoa Hwe Koan school, 中華會館, hereafter THHK), was established in 1901 in Patekwan, Batavia. ${ }^{43}$ Motives for establishing THHK were diverse. Some historical documents and scholarship stated that THHK's primary goal was to modernize and correct misinterpreted Chinese traditions, while other sources pointed out that THHK provided a practical curriculum that would help increase Indies Chinese competitiveness in commerce and other professions. Indies Chinese who desired treatment that was equal to what Europeans and Japanese received saw education for Chinese children as a way to improve the deteriorating position of Indies Chinese relative to others in the colony. ${ }^{44}$ Regardless of THHK's initial motives, the establishment of the institution did not benefit Dutch rule, for THHK reinforced its students' cultural and national ties with China. According to Henri Borel, THHK's significance resided in "the spirit that emanated from the school movement ... [it is important] not so much for the present, but for the future. That spirit sought in the first place enlightenment and advancement for the Chinese, and was in the second place strongly Chinese-nationalistic." ${ }^{45}$

Although the Dutch government was wary about the establishment and popularity of THHK-type schools, it was not until 1906, when authorities saw the increased aggressive intervention of the Chinese state, that the Dutch government made a major shift in its educational policies. Two developments ignited Dutch anxiety. The first was

\footnotetext{
${ }^{41}$ DNA 2.05.90-528, "Overheidscontrole op particulier Chineesch Onderwijs"; Mona Lohanda, The Chinese and the Dutch in Colonial Java, 1890-1942 (Jakarta: Yayasan Cipta Loka Caraka, 2002), pp. 50-62.

${ }^{42}$ BB 2194/32.

43 "Chinese Association" is a loose translation of "Tiong Hoa Hwe Koan." THHK schools were opened by the THHK association. The first THHK association was established in Batavia in 1900. Considered to be the first pan-Chinese association in the Dutch East Indies, THHK bridged the barriers between peranakan Chinese and singkeh Chinese and included members from various Chinese dialect groups. A great number of THHK branches and THHK schools were opened throughout the Dutch East Indies after the Indies Chinese opened the first branch in Batavia. See Lea E. Williams, Overseas Chinese Nationalism: The Genesis of the Pan-Chinese Movement in Indonesia, 1900-1916 (Glencoe, IL: Free Press, 1960).

${ }^{44}$ Kwee Tek Hoay, The Origins of the Modern Chinese Movement in Indonesia (Ithaca, NY: Cornell Southeast Asia Program, 1969), pp. 8-21; Charles Coppel, "The Origins of Confucianism as an Organized Religion in Java, 1900-1923," Journal of Southeast Asian Studies 12,1 (March 1981): 179-96; P. H. Fromberg, Verspreide Geschriften (Leiden: Leidsche Uitgeversmaatschappij, 1926), p. 450; Williams, Overseas Chinese Nationalism; and Ming Govaars-Tjia, Dutch Colonial Education, p. 61.

${ }^{45}$ Borel's quote was taken from Ming Govaars-Tjia, Dutch Colonial Education, p. 62.
} 
that Japan was growing in power and might one day collaborate and become partners with China in opposing Western colonialism. ${ }^{46}$ As the quotation at the beginning of this essay revealed, Japan's victory in the Japan-Russo War in 1905 sparked hope among Asians who were victims of Western imperialism. Japan became a model for China and Chinese people. A student from THHK in Batavia, for example, wrote in an essay: "China is so much bigger than Japan! How magnificent could we become if the great China reorganizes! We could become the most powerful nation in the world, but first we need education to reach that goal." ${ }^{47}$

The second development was the intensifying relationship between Indies Chinese and the Chinese state through educational organizations such as THHK, but especially via the reopened Jinan. Since its establishment in Nanjing in 1906, Jinan aimed at training Indies Chinese children to become leaders of the anticolonial movement. According to Dutch officials, they were given the task of stirring the larger Indies Chinese community to sever political allegiance (staatsverband) with the Dutch empire. Jinan, operating under the Viceroy of Nanjing (who called himself the Grand Official of the South Seas [南洋大臣]), was established initially as a school to nurture Dutch Indies Chinese to become more oriented towards the Qing government. According to a Dutch official, students were taught to learn the Chinese language, math, geography, history, music, and even arms trade. Most concerning was that Jinan's approximately one hundred students between twelve and eighteen years old looked more like Javanese than "their yellow brothers." Many students were Chinese descendants mixed with Malay blood, spoke Malay, had short hair, and wore Indo-European clothes instead of pigtails and Chinese dress. Dutch authorities were concerned that Jinan made Malaylooking Chinese become oriented towards the Chinese government. Moreover, they were worried that these young students would, upon their return to Java, spread Chinese nationalistic sentiments among the indigenous population. ${ }^{48}$ Chinese officials started to establish a system of political interference by stirring Jinan students to act against Dutch power. Dutch Consul-General Von Zeppelin confronted the Qing state in 1909 on this matter, but Dutch authorities found that Jinan's mission, goals, and attitude remained unchanged after it reopened. ${ }^{49}$

Jinan closed after the fall of the Qing empire (1912), but reopened around 1917, as noted above. Compared to British authorities, Dutch officials were more anxious about Jinan's reopening. Seeing it as part of China's resurrection of Sino-centrism, which held on to the notion that Chinese emperors were rulers, followed by vassals who controlled the power beyond the center, ${ }^{50}$ the Dutch empire was positioned as the bad ruler that was doomed to lose power. ${ }^{51}$ Therefore, Dutch authorities strongly resisted Jinan's growth, for in their minds, "Jinan was the principal stronghold of Chinese

\footnotetext{
${ }^{46}$ DNA 2.05.03 -578.

${ }^{47}$ L. H. W. van Sandick, Chineezen buiten China: Hunne Beteekenis voor de Ontwikkeling van Zuid-Oost-Azië, speciaal van Nederlandsch-Indië ('s Gravenhage: M. van der Beek's Hofboekhandel, 1909), p. 255.

${ }^{48}$ DNA 2.05.03-41, Afschrift No 1196/106 (Shanghai, 7 July 1908).

${ }^{49}$ DNA 2.05.90-528, "Bijdrage voor het Pekingrapport van 1924 no. 24."

${ }^{50}$ DNA 2.05.90-528, "Afschrift Kantoor voor Chineesche Zaken to Gouverneur-Generaal van Nederlandsch-Indie," pp. 7-8 (Weltevreden, September 13, 1923).

${ }^{51}$ Ibid.
} 
imperialism in the modern period that should not be welcomed by the colonial powers in Asia." ${ }^{52}$

\section{Controlling the Flow of Students, Teachers, and Consuls}

\section{Students}

Dutch authorities implemented and enforced strict border controls after Jinan resumed its anticolonial cause when it reopened in 1917. Many students at Jinan came from the Indies and reinforced Dutch fears that students were trained to become extremists advocating anti-Western rule. ${ }^{53}$ Therefore, viewing Jinan students as dangerous agents bent on spreading Chinese imperialism overseas, Dutch immigration officers prevented Indies Chinese students from returning to the Indies upon receiving their education at Jinan. ${ }^{54}$

Soon after Dutch authorities implemented new border restrictions, the Chinese government initiated improved diplomatic relations with Holland by inviting Dutch officials to visit the school. However, H. Mouw, an official holding the post of Adviseur at the Bureau of Chinese Affairs starting from 1919, mistrusted China's efforts to repair Sino-Dutch diplomatic relations. ${ }^{55}$ Since the school's establishment, Jinan had taken a hostile stand against Dutch rule, but Dutch officials were particularly suspicious about Jinan's strong relationship with the Colonists' League (Lianhehui, 聯合會). The Colonists' League was intensely involved in overseas Chinese affairs and led the Chinese re-nationalization campaign at the time. ${ }^{56}$ With branches extending over the port cities in Southeast Asia and coastal cities in China, the league worked closely with overseas Chinese communities, Chinese associations, and local and central governments in China. Strong connections between the league and Jinan were evident. For example, in 1923 the league's secretary took a Dutch official on a tour of Jinan. During this meeting, the secretary showed the Dutch official Jinan yearbooks from 1922 and 1923. Most students in those books were not allowed to return to the Indies, due to the Dutch prohibition that forbade Jinan students from reentering the Indies. ${ }^{57}$

Dutch concerns regarding a steady influx of radicalized students returning from China were exaggerated. In fact, according to a Dutch official based in Shanghai, many

\footnotetext{
${ }^{52}$ DNA 2.05.90, Afschrift Kantoor voor Chineesche Zaken No. 514/ 23, Zeer Geheim, p. 4.

${ }^{53}$ F81, "The Chinese Movement in Netherlands India," p. 3.

${ }^{54}$ DNA 2.05.90-528, document no. 2754/ 134 (Shanghai, December 13, 1923). Although Dutch officials found that not all students at Jinan upheld an "extremist" approach to the colonial government, Dutch officials rejected most graduates' requests to enter the country. Some students who were permitted entry to the Indies were later asked to leave the colony.

${ }^{55}$ DNA 2.05.90-528, Bijdrage voor het Pekingrapport van 1924 No. 24 (March 19, 1924).

${ }^{56}$ The Colonist's League (Lianhehui) was established in 1911 by Bai Pingzhou, who was anti-Dutch. He was involved in the Chinese naturalization campaign of 1908-09. The League served as a middleman for the movement against Dutch naturalization and turned its building into the headquarters of the movement. The League also engaged in educational and economic affairs. In the early 1920s, it was involved in Jinan's affairs and, at the same time, intervened in the campaigns to revoke restrictive European laws in the South Seas, seeking to benefit China's industry. DNA 2.05.90-528: Kantoor voor Chineesche Zaken Document no. 68/34 (Weltevreden, January 25, 1924).

${ }^{57}$ DNA 2.05.90-528, document no. 2754/134, Dutch Consul General in Midden-China (Shanghai, December 13, 1923).
} 
students at Jinan stayed in China after their graduation with the purpose of establishing branch offices of their family businesses that were headquartered in the Dutch colony. Their primary goal for attending Jinan had been merely to acquire business skills, general knowledge, and language proficiencies that were useful for commerce. ${ }^{58}$ These students were not interested in fulfilling China's political expectations and were primarily interested in advancing and expanding their family businesses from the Indies to China.

\section{Teachers}

Students were not the only transnationals who were perceived as a threat by colonial authorities. Besides preventing Jinan's students from re-entering the Dutch colony, the Dutch government also enforced strict border controls limiting the entry of teachers. The network connecting the Chinese government and Chinese schools, particularly the THHK, was tight. Most Chinese teachers who relocated to Southeast Asia came from China's coastal areas. In January 1925, for example, three teachers originating from Jiangsu went to Java and Billiton. In addition, three educators went to Batavia to work at THHK. One educator from Zhejiang became head of the school while two educators, one from Jiangxi and one from Jiangsu, were hired as instructors. ${ }^{59}$

The institutionalization of Jinan's teacher-training program and the organization's decision to admit female students accelerated the enactment of stricter measures by the colonial power. After launching the training program, Jinan regularly sent teachers to work at Chinese schools in Southeast Asia. Dutch authorities regarded teachers who were sent by Jinan as products of anti-Western imperialism, and believed that each teacher was an extension of Jinan. ${ }^{60}$

The school had been increasingly sending male and female graduates overseas to work at Chinese schools. Fearing that anti-Dutch thoughts would infiltrate the Indies, a colonial advisor of Chinese affairs wrote:

The purpose is clear: Jinan continuously tries to make the mobile youth active and make them serve the interests of the fatherland and resist the colonial

\footnotetext{
${ }^{58}$ DNA 2.05.90-528, "Onderwijzend personeel uit China voor Indië," from Neth. CG in Midden China (Groeneman) to Mr. WF Roëll, Legation in Beijing (Shanghai, August 7, 1925); DNA 2.05.90-528: Bruineman (Adviseur/ Hoofd van den Dienst der Chineesche Zaken). Bijdrage voor het Pekingrapport van 1923 No. 73, "Toelating van Chineesche onderwijzers in Nederlandsch-Indië, afkomstig van de school te Nanking [Chinan Institute]."

${ }^{59}$ 2.05.90-528, Consulaat-Generaal der Nederlanden voor Midden China, doc no. 1881/113,

"Onderwijzend personeel uit China voor Indië" (Shanghai, August 7, 1925). The additional information that follows gives an idea of the reach of Chinese teachers from coastal China who were sent to teach at THHK branches in the Indies. Jiangsu had a strong network linking it to Batavia and the Outer Islands, in particular. In February 1925, one teacher from Anhui went to Bangka, a teacher from Zhejiang went to Deli, and a teacher from Kiangsu went to Batavia. In March 1925, two teachers from Hunan went to Pekalongan; in July 1925, one teacher from Jiangsu went to Bangka; and in August 1925, three teachers from Kiangsu went to Pontianak.

${ }^{60}$ In 1923, for example, two female teachers, Hsia Sung Wei and Chen Chao Yang, were refused the chance to teach in the Indies because, according to the Department of Justice, they had studied at Jinan. See DNA 2.05.90-528, Afschrift Departement van Justitie No. 2/3/16 (Weltevreden, September 21, 1923).
} 
government that is represented in propaganda as a usurper and an oppressor.... Interference can no longer be tolerated otherwise recently implemented inspections on teachers would be useless. ${ }^{61}$

Dutch government actions prompted a streamlining of the exchange of information between the Dutch consulates in Beijing, Shanghai, and the colonial government in the Indies. In order to remove enemies from their territory, the Dutch Immigration Office monitored teachers' behavior and updated their information regularly. Dutch authorities in Shanghai did not issue visas for instructors without consulting the Indies government. The consuls-general did not issue permits unless they had sufficient reassurances that proved that the teachers were not propagandists. ${ }^{62}$

Policy barriers that blocked Chinese teachers from entering the Dutch Indies reached their height in 1925 . One authority wrote about the necessity to keep the colonial borders closed to extremist instructors. ${ }^{63}$ This expression emerged when GMD's anticolonial voice has risen to its highest pitch. Fearing that the GMD would "awaken the rebellious spirit" among the overseas Chinese resident in the colony, the Dutch government strictly prohibited access to education for GMD members and refused teachers from Jinan entry to the Dutch East Indies. The danger of "poisoning" children with Chinese education (vergiftiging van het Chineesche onderwijs) came particularly from GMD members who diligently followed their duty of propagating the party's principles through the curricula. These members, Dutch officials believed, encouraged students' involvement in political demonstrations. ${ }^{64}$

\section{Consuls}

Besides limiting the circulation and influence of teachers, students, and political thoughts, the Indies government struggled to block the intervention of Chinese officials in Chinese schools. One such case arose following the establishment of a Chinese Middle School in Surabaya in 1929. In this year, Mouw reported that the first signs of the Chinese government's interference in the education of the Indies Chinese had emerged. From these signs, Dutch authorities discovered that the Chinese were carrying out two contradictory policies simultaneously. Despite China's 1914 agreement with Holland that it would follow a policy of non-interference, Dutch officials uncovered a document revealing that consular intervention in educational affairs was of utmost importance for China. This document, from China's Ministry of Education, stated that engaging with educational affairs was an integral task of Chinese consuls, including those who were stationed in the Dutch East Indies. ${ }^{65}$ On the one hand, it was obvious that, at the level of international politics, China adopted a conformist policy of non-interference in the affairs of overseas Chinese. On the other

\footnotetext{
${ }^{61}$ DNA 2.05.90-528, Bruineman (Adviseur/ Hoofd van den Dienst der Chineesche Zaken). Bijdrage voor het Pekingrapport van 1923 No. 73, "Toelating van Chineesche onderwijzers in Nederlandsch-Indië."

${ }^{62}$ DNA 2.05.90-528: "Onderwijzend personeel uit China voor Indië" (Shanghai, August 7, 1925); ibid.

${ }^{63}$ DNA 2.05.90-528, C.S. Shanghai 1009/71 (Beijing, July 21, 1925).

${ }^{64}$ DNA 2.05.90-528, Uitreksel Ag. 932x), 2613x)24, 2035x), 1. Algemeene onderwijsverbod voor leden der Kuo Min Tang; 2. Wering van Chinan-leerkrachten.

${ }^{65}$ DNA 2.05.90-528, Peipingrapport no. 99/29, doc. no. 80/3 (Batavia, August 13, 1929); Afschrift no. 261,

"Bemoeiing van den Chineeschen Consul met onderwijsaangelegenheden" (Buitenzorg, August 13, 1929).
} 
hand, at the national and domestic levels, China continued to strengthen its ties with overseas Chinese communities and coordinated its educational outreach initiatives by way of its consuls overseas.

GMD consuls-general were clearly involved in establishing middle schools in Batavia and Surabaya in this period. ${ }^{60}$ Based on police reports from Surabaya in 1929, Mouw concluded that the Chinese consul had been engaged in the establishment of the Chinese Middle School in Surabaya (Heshu Huaqiao Xuetang, 荷屬華僑學堂). ${ }^{67}$ A report revealed that, on the advice of the consul, the school recruited two Chinese instructors who had received their education in the United States. Under the supervision of the consul, three elected committee members of the school board examined teachers' skills and credentials. A consul-in-training was appointed to manage daily affairs. In 1929, the school board was in the process of launching school propaganda, asking for donations, and preparing for students' entry exams, with the aim of opening its new school in September. ${ }^{68}$

In order to deny Chinese consuls the opportunity to interfere in local educational affairs in Surabaya, in 1929 Mouw referred to a written statement dated May 18, 1914, in which China's Minister of Foreign Affairs at the time, Sun Baoqi (孫寶琦), guaranteed that Chinese consuls who were posted in the Dutch Indies would not intervene in educational matters. ${ }^{69} \mathrm{He}$ also asked the Governor-General to use this statement to serve as a warning for the Chinese consul, demanding that he cease his involvement in local education since such actions were in conflict with the Sino-Dutch agreement. $^{70}$

Although the Chinese consul in Surabaya played a leading role in the construction and organization of the school, the request to build a school had come from Li Shuanghui (Lie Siong Hwie, 李雙輝), a former president of the Chinese Chamber of Commerce in Surabaya. In his letter to the Chinese consul in Surabaya, he stated: "When I arrived here, I saw that there was no continuing education for 30,000 children.

\footnotetext{
${ }^{66}$ DNA 2.05.90-528, "Bemoeienis van den Chineeschen Consul te Soerabaja met onderwijsaangelegenheden" (August 3, 1929). In Perniagaan, July 22, 1929, the Chinese consul-general in Batavia announced that he was trying to establish a middle school in Batavia. Li Shuanghui and the consul-general in Surabaya were in the process of building a similar school in Surabaya in this period.

${ }^{67}$ DNA 2.05.90-528: 2.05.90-528, Algemeene Politie Soerabaya Afdeeling Politieke Inlichtingen Dienst Chineesche Zaken no 220, "Bemoeienis van den Chineeschen Consul te Soerabaja met onderwijsaangelegenheden" (August 3, 1929).

${ }^{68}$ DNA 2.05.90-528, Algemeene Politie Soerabaya Afdeeling Politieke Inlichtingen Dienst - Chineesche Zaken no 220. Police report with regards to the school's committee meeting on July 19, 1929, dated July 23, 1929, by officer Friehs. These teachers were: Zheng Paoyuan (鄭保元), who received his doctoral and medical degrees in the United States. When his wife, Lin Yuying (栤玉烡), was twenty-eight years old, she obtained her doctoral degree and was sent to the United States by Chin Kua University at the government's expense. They were in Singapore and were going to Surabaya (also see news article, Kiauw Sing Djit Po, Surabaya July 23, 1929). Participants included Li Shuang Hui (李隻輝, Lie Siong Hwe), Consul Guo (郭領事, Consul Kuo), Thio Tjee An (張濟安), Oen Siauw Giok, Yap Djim Swi (葉壬水), Poh Kho Eng (傅可䔄), Ko Han Tjong (古漢宗), Lee Kong Yauw, Lie Kong It, Lim Tjeng Hoen, Gouw Sie Soen, Tjioe Tjeng Yan, Yap Tan Boe, Kiauw Im Kong, Koh Siok Hoek, and Tjou Toen Bwe.

${ }^{69}$ DNA 2.05.90-528: "Bemoeiing van den Chineeschen Consul met onderwijsaangelegenheden." From Algemeene Secretarie in Buitenzorg, August 13, 1929, to GG in Eastern Java. Sun Baoqi, a Qing official and a supporter of Yuan Shikai, served as minister of foreign affairs in 1913 and 1914.

${ }^{70}$ DNA 2.05.90-528: Kantoor voor Chineesche Zaken no. 568/29, "Bemoeienis Chineesche Consuls met onderwijsaangelegenheden" (Weltevreden, August 3, 1929).
} 
Hence, I proposed to establish a middle school in Surabaya, with the purpose of maintaining the level of education and development for Chinese immigrants. ${ }^{171}$ Li's $^{\prime}$ outreach to the Chinese consul prompted the colonial government to tackle the matter directly and forcefully with the Indies Chinese community. The provincial governor warned Li Shuanghui, who had been appointed president of the new middle school, that the Chinese consul was not allowed to intervene in educational affairs. If the school deviated from this rule, the colonial government would revoke its agreement to permit those instructors to teach in the Indies. The colonial government asserted its power to employ legal documents when matters threatened its authority, and it cited a governmental regulation (staatsblad 1923 no. 136) to declare that the relationship between Chinese residents and Chinese consuls endangered the interest of the colony and threatened its long-term goal of maintaining public peace and order. ${ }^{72}$

\section{Fragile Borders}

As noted above, in 1914 the Dutch government signed an agreement of noninterference with China's minister of foreign affairs (during Yuan Shikai's rule). In an attempt to prevent consuls from overstepping their authority, Dutch officials forced the Chinese to state in a consular agreement that consuls were allowed only to engage in commercial—not educational-activities. The 1914 agreement highlighted the fact that consuls' interference with local education was strictly forbidden. However, as the example in 1929 showed, the regulations and policies only had limited effect, as Chinese officials continued participating in educational matters.

Although preventing Chinese instructors and students from entering European colonies helped to reduce the spread of Chinese "imperialist" ideas, stringent border controls never succeeded in completely eliminating the circulation of political ideas and the intervention of the Chinese government in educational affairs. A report from 1929 that notes thirty-three cases in which teachers were arrested and banned from instructing students, for example, showed that colonial authorities continued to face the threat that students were being politically indoctrinated at Chinese schools. ${ }^{73}$ Politically active teachers listed in this report were concentrated in Java, but the document also mentioned some instructors teaching in Sumatra, Borneo, and Menado. They were charged with spreading political propaganda, such as teaching Sun Yatsen's doctrine of "Three Principles of the People," and for using teaching materials that contained political messages. Many arrested instructors were expelled from the Indies; some teachers were held in prison, while others were forced to stop teaching for

\footnotetext{
${ }^{71}$ DNA 2.05.90-528: Li Shuanghui's letter to Chinese Consul Guo in Surabaya; originally from Sin Po 25 (April 1929).

${ }^{72}$ DNA 2.05.90-528: Kantoor voor Chineesche Zaken No. 568/29, "Bemoeienis Chineesche Consuls met onderwijsaangelegenheden." (Weltevreden, August 3, 1929.

${ }^{73}$ This report also contained information about punishments meted out by the Siamese government. Dutch and Siamese governments punished fifty-two Chinese instructors, out of whom nineteen instructors were penalized by the Siamese government. Generally speaking, Siamese punishments were more severe than Dutch punishments. See Qian He, “huaqiao xuexiao zhiyuan chujing ji beibubiao" (華僑學校教職員出境及 被捕表), in Nanyang huaqiao xuexiao zhi diaocha yu tongji, ed. Qian He (Shanghai: Dahua, 1930).
} 
reasons that are unclear. Dutch officials also examined students. In one case, a teacher was forced to leave his post after his student wrote an essay about judicial equality. ${ }^{74}$

\section{Dutch Affirmative Policies}

One of Holland's relatively subtle methods for decreasing Indies Chinese political orientation towards China was to try and make Indies Chinese more Dutch-oriented. Paranoia about the flow of anti-Dutch ideas prompted Dutch authorities to open Hollandsche-Chinese schools (Dutch Chinese public school, hereafter HCS) in 1908. Witnessing the power of education for nourishing Chinese national consciousness, Dutch authorities, by following the example of the Chinese government, aimed at engendering allegiance and political loyalty through their own schools. HCS were aimed at the Chinese (especially peranakan Chinese) and monitored by the Dutch government. Overall, HCS were successful in attracting and educating Indies Chinese students. HCS were opened under the same conditions as schools for indigenous inhabitants. Instruction was completely in Dutch, and the curriculum was similar to curricula at European primary schools. Admission to HCS was conditioned upon sufficient proficiency in the Dutch language. ${ }^{75}$ Some Indies Chinese regarded these schools as a good start in progress toward an effective public educational program, but were not completely satisfied. Tan Siauw Lip, from Semarang, who held the rank of Kapitein, for instance, found that the Dutch attempt to meet the educational needs of Chinese children was all well and good, but he also expressed the wish that Chinese children be allowed to take exams under the same conditions as Dutch children. He also hoped that Chinese people would receive the same job opportunities as did the Dutch. ${ }^{76}$ Indies Chinese responses to $\mathrm{HCSs}^{\prime}$ establishment revealed that their main goal was to obtain equal rights and status in the colony.

The first HCS opened in 1908, a little over a year after Jinan's founding. The HCS curriculum aimed at "Dutchifying" Indies Chinese, and so contrasted with the curricula of THHK, which aimed at "Sinification." Fearing that Indies Chinese students were becoming increasingly politically supportive of a Chinese empire, Dutch authorities wanted to reduce the wave of Chinese nationalism in the Indies and reinforce Dutch authority over its subjects by implementing affirmative policies. ${ }^{77}$ They were concerned by the activities of both THHK and Jinan. Like the Chinese, the Dutch sought to use education as a means to inculcate loyalty. They hoped to nourish the Chinese sense of inclusion within colonial society through the HCS.

\footnotetext{
${ }^{74}$ This fascinating list released names of detainees and "colonial violators." It also revealed the names of schools where these instructors were employed, their punishments, and the reasons and dates for punishment. A number of instructors spread anti-foreignism, and taught the youth to "hate foreigners" and to organize boycott committees with the purpose of boycotting foreign goods. Teachers who arrived in the Dutch Indies often used textbooks that were based on Sun Yat-sen's "Three Principles" (sanmin zhuyi). Dutch officials prohibited instructors who taught anti-foreignism or used sanmin zhuyi to continue teaching. See Ibid.; and F81 \#29, 34, and 36.

${ }^{75}$ L. H. W. van Sandick, Chineezen buiten China: Hunne Beteekenis voor de Ontwikkeling van Zuid-Oost-Azie, special van Nederlandsch-Indië ('s Gravenhage: M. van der Beek's Hofboekhandel, 1909), pp. 204-5.

${ }^{76}$ Ibid., p. 206.

${ }^{77}$ Wen Guangyi [溫廣益], Yind unixiya Huaqiao shi [印度尼酉亞華筒史] (Beijing: Haiyang, 1985), p. 461.
} 
106 Oiyan Liu

\section{Two Competing Teacher's Programs: Jinan and HCS}

In 1920, Jinan added the Teacher's Program to its curricula. This program trained Chinese students from overseas as teachers, so that they might take their knowledge to Southeast Asia upon graduation. Following Jinan, the Dutch, likewise, soon extended their educational program by establishing a Teachers' School in Meester Cornelis, in Eastern Batavia, where Indies Chinese students received training to become instructors at HCS. Previously, teachers at HCS were solely of Dutch descent, but with the HCS Training Program, the Dutch government aimed at training Indies Chinese to become teachers in their own communities. They believed that this system would be more effective for nourishing loyalty to the Dutch state. This belief was further strengthened after the Dutch witnessed how the British Education Bill of 1920 aggravated SinoBritish relations and escalated Chinese discontent in British Malaya.

Dutch authorities established the general training school in 1917. By 1920, this school underwent a complete reorganization, after which its goal was to train exclusively teachers of Chinese descent who would teach at HCS after graduation. During their five years of instruction at this boarding school, teachers-in-training would learn skills for teaching classes with a maximum of twenty-five students under the supervision of the local committee of European schools (Europeesche Schoolcommissie) and Inspecteur of Lager Onderwijs. The coursework was determined by the Director of Education and Religion (Onderwijs en Eeredienst). Students learned the Dutch language and writing, math, biology, musicology, drawing, pedagogy, gymnastics, arts, and violin, as well as the history and geography of the Netherlands and the Dutch Indies. Like Jinan, Dutch authorities also included courses that would meet the demands of the Indies Chinese community. The curricula concentrated on practical learning and offered instruction in the Chinese language, but did not offer Chinese history or geography classes. It also accommodated Chinese celebrations in addition to Christian and Dutch national holidays. Thus, the content of HCS coursework was, in many aspects, similar to the curricula that Jinan and THHK offered; both Dutch-oriented and China-oriented education also took into account the demands of Indies Chinese who desired to receive education in practical learning for professions such as commerce. ${ }^{78}$ Dutch training schools also resembled Jinan's training schools in terms of their underlying purpose: both aimed at training Chinese teachers to be loyal to the state. These teachers, who served as intermediaries between the state and the masses, would then, ideally, further disseminate loyalty toward the state to the rest of the Chinese community.

Strict admission requirements and the lack of statistical data make it difficult to evaluate the results of the Dutch teacher-training program. Selection criteria for attending the school were extremely restrictive. Only students who graduated from seven years of HCS schooling or a European school (Europeesche school) were eligible to apply for admission. The head of the education department then determined who would be accepted or rejected. Students who failed to work hard, whose proficiency in the Dutch language was insufficient, who exhibited improper behavior, or who suffered from contagious diseases risked being suspended from school.

\footnotetext{
${ }^{78}$ DNA 2.05.90-528: "Ontwerp leidraad voor de Kweekschool tot Opleiding van Chineesche onderwijzers en onderwijzeressen bij het Hollandsch Chineesch onderwijs" (Batavia, April 10, 1920).
} 


\section{Education and Naturalization}

HCS admission requirements for the teacher-training programs included Dutch naturalization (onderdaanschap).$^{79}$ The introduction of this new educational program in the Dutch colony was closely interwoven with the Chinese naturalization movement that took place in this period simultaneously. Between 1917 and 1921, in an attempt to escape from Dutch colonial treatment, Dutch Indies Chinese, in collaboration with the aforementioned Colonists' League, aimed at invalidating their status as Dutch subjects by sending petitions to the Chinese government with the request that they be naturalized by China. Propagators of this movement had strong connections with Chinese educational institutions and associations. They were involved in expanding and stimulating Chinese education among the Indies Chinese. ${ }^{80}$

Dutch authorities hoped to end the growing Chinese naturalization movement among the Indies Chinese and win the political allegiance and loyalty from Indies Chinese by implementing educational policies that would benefit the Indies Chinese. Therefore, educational policies and opportunities for the Indies Chinese were intrinsically intertwined with Dutch policies regarding nationality issues. School attendance was limited to boys and girls who were naturalized as Dutch subjects. The Dutch government was mostly concerned with subjects of Chinese descent, more than other minorities, for this group "dealt with the onderdaanschaps issue most unpleasantly." ${ }^{81}$

Two reasons motivated Dutch authorities to include nationality requirements in its educational policy. First, limiting HCS admission to Dutch subjects exclusively would attract, secure, and further cement Indies Chinese loyalty to the Dutch state. Second, by making the school available only to Dutch subjects, Dutch authorities expected that it would encourage members of the Indies Chinese population to become naturalized Dutch subjects. Being conscious that Chinese education contributed to Indies Chinese desires of becoming Chinese nationals, the Dutch were convinced that problems with regards to education and nationality were closely connected. In his report to Beijing, Bruineman, chief of the Chinese affairs office, stated that an advantage of becoming a teacher at HCS training schools was that it required Dutch naturalization, which was attractive to the Chinese. ${ }^{82}$ The Dutch office for Chinese affairs expressed the opinion that, when the Dutch metropolitan and colonial governments imposed the Law of Dutch subjectness or Naturalization Law (Onderdaanschap) on the Indies Chinese by force in 1910, with the purpose of officially claiming Indies Chinese as Dutch subjects, Dutch authorities paid insufficient attention to the educational issue. According to Dutch officials, failing to take educational benefits into account had caused the movement against Dutch naturalization to rise and spread extensively. ${ }^{83}$ Therefore, by including naturalization conditions in its educational policies, Dutch authorities

\footnotetext{
${ }^{79}$ Ibid., Article 12.

${ }^{80}$ AS 03-23-023-02-011; AS 03-23-024-01-007; AS 03-23-023-03-011; AS 03-23-025-03-013.

${ }^{81}$ DNA 2.05.90-528: Afschrift no. 365/ 20 (dated Weltevreden, June 19, 1920).

${ }^{82}$ DNA 2.05.90-528: Afschrift no. 333/IIa (dated Batavia, August 3, 1920).

${ }^{83}$ DNA 2.05.90-528: Afschrift no. 365/ 20 (dated Weltevreden, June 19, 1920).
} 
attempted to resolve two problems (namely, Indies Chinese need for Chinese education and their desire for obtaining Chinese nationality) that otherwise would benefit China's expansionist ambitions but were potentially disastrous for Dutch authority.

While these innovations were intended to attract support and allegiance from the Indies Chinese, the educational initiative also intentionally sharpened a division, separating the existing Indies Chinese population from new immigrants (also called totoks or singkehs). By allowing only Chinese students with Dutch naturalization to attend HCS, the Dutch made an attempt to segregate peranakan from singkeh. Bruineman requested privileging peranakan Chinese above singkeh by amending staatsblad 1908, sub I, and by not allowing singkeh to attend HCS schools. ${ }^{84}$ Bruineman explained that the rules the Dutch government created for the Chinese had been applicable to both peranakan and singkeh-people that the Dutch government regarded as, respectively, subjects and non-subjects. Yet, disadvantageous regulations, such as the conscription law, only applied to Dutch subjects. The conscription law and problems with Chinese consular protection became recurring complaints after the Kudus incident took place and motivated Dutch subjects of Chinese descent to discard their Dutch status. ${ }^{85}$ The Dutch affirmative policy on education was therefore a way for the Dutch government to prevent its subjects from seeking favor with China versus being naturalized as Dutch. To safeguard emotional attachment, according to Bruineman, it was important that the Indies Chinese would feel privileged. The many requests for establishing and expanding schools, and parents' expressions of disappointment when their children were rejected for admission, revealed that the Indies Chinese were not entirely dissatisfied with Dutch educational policies; they aspired to enter their children in the HCS schools, but wanted, even expected, good public schooling to be made more widely available. ${ }^{86}$

Furthermore, solely admitting peranakan Chinese would help counter political influence from China that was often spread by singkeh. In the opinion of Dutch officials, singkeh imported direct influences from China and were largely nationalistic; they would hinder the Dutch goal of nourishing peranakan Chinese with "a sense of commonness" (gevoel van saamhorigheid) regarding the Dutch state. In particular, Bruineman strongly opposed ever allowing a singkeh Chinese to become head or an advisor at the training school for $\mathrm{HCS}^{87}$ for, as this essay shows, Dutch authorities were particularly concerned with the imperialist, anticolonial thinking that recent migrants from China brought to the Indies.

\section{Conclusion}

"The Chinese threat" is not a new topic in the study of Dutch colonial rule. Feeling threatened by the increasing and widespread economic power of the Indies Chinese, the Dutch colonial government, as the scholarship on Indonesian Chinese has shown,

${ }^{84}$ DNA 2.05.90-528: Afschrift no. 333/Ila (dated Batavia, A ugust 3, 1920).

${ }^{85}$ DNA 2.05.90-528: Afschrfit no. 365/20/ zeer geheim, p. $2 X$.

${ }^{86}$ DNA 2.05.90-528: Afschrfit no. 365/20/ zeer geheim, p. 2.

${ }^{87}$ Ibid. 
drew geographic and racial boundaries to control the power of the Chinese throughout the nineteenth century. As explained above, in order to safeguard Dutch interests, Dutch officials monitored the Chinese by confining their mobility with the quarter system and pass system. Many studies of this topic have made reference to the impact of China's interest in Indies Chinese affairs on the political orientation of the Indies Chinese. What is lacking, however, is a study of how China's increasing interference changed Dutch perceptions of threat. In this essay, I argue that, although the Dutch evidenced Sinophobia in the first decade of the twentieth century, the 1920s was a crucial period, for during that decade Dutch perceptions shifted, and the authorities began to perceive China, rather than resident Indies Chinese, as the true threat. This shift resulted in a change of Dutch border policies, as drawing geographic and racial boundaries within the colony was no longer of primary importance. Instead, to protect Dutch possessions, it was necessary to enforce border policies to thwart external influences.

Launching border protections against China's influences was not limited to the Dutch East Indies. British authorities, too, were concerned about China's expansionism as it related to Southeast Asia. Europe's escalating fear of what it perceived as "Chinese imperialism" in the 1920s was coupled with the multiplication of border controls and educational policies that helped limit transnational interactions between China and the Chinese communities in both Dutch and British dominions. The proliferation of GMD-guided schools, GMD's war against Western imperialism, and the reopening of Jinan College in 1917 sparked widespread colonial anxiety in British and Dutch Asia. Jinan was the school that Dutch authorities described as "the fortress of Chinese imperialism," an enterprise that used education for overseas Chinese as a means of "peaceful penetration" to extend its sphere of influence to colonial Southeast Asia. Colonial authorities were anxious because the school not only nourished anticolonial sentiments, but it also promulgated the idea that Southeast Asia should be ruled by Chinese people. Because of prevailing Sinophobia in the region, both British and Dutch colonial authorities launched educational policies that obstructed the spread of Chinese expansionism.

Whereas British authorities attempted to eradicate political ideological influences on Straits Chinese by launching its Education Bill in 1920, the Dutch government adopted both discriminative and affirmative policies. Discriminative actions included barring certain students, teachers, and Chinese officials from entering the Dutch colony. Meanwhile, Dutch authorities, for the first time in 1908, opened public schools exclusively for the Chinese, though, as noted above, these schools were effectively reserved for the peranakan Chinese, not totok or singkeh Chinese. In doing so, Dutch authorities attempted to compete with local Chinese schools, especially THHK, that were connected with the Chinese government and Jinan. HCS curricula were in many aspects comparable with THHK's coursework. From its observations of Chinese schools, the Dutch government noticed that education was a powerful weapon for evoking a sense of Chineseness. Schools were a powerful medium for narrowing the ties between Chinese authorities and the overseas Chinese. Therefore, when Jinan opened its teacher's program with the purpose of training students to become educators at overseas Chinese schools, Dutch authorities, using a similar rationale, opened a teacher's program to train Dutch subjects of Chinese descent to become HCS teachers. From the Dutch viewpoint, having Indies Chinese students receive 
instruction from Indies Chinese teachers would be an effective way to decrease the popularity of Chinese schools and attract Indies Chinese support and loyalty to the Dutch state.

This essay has approached the proliferation of border control and both discriminative and affirmative educational policies from the perspective of Europe's paranoia regarding the Chinese threat. It has also showed that Dutch fixation on protecting its colonial borders and the efforts of eradicating Chinese imperialist ideas flowing into the colonies caused Dutch authorities (perhaps unwillingly and unintentionally) to create new educational and naturalization opportunities for the Indies Chinese.

\section{Archives}

AS (Academia Sinica, Taipei)

BB (Binnenlandsch Bestuur, Arsip Nasional Republik Indonesia)

CO 273 (Colonial Office 273, National University of Singapore)

DNA (Dutch National Archives), or National Archives of the Netherlands, The Hague F81 (Arsip Nasional Republik Indonesia)

MBPI (Malayan Bulletin of Political Intelligence, National Archives of Singapore) 